\title{
Development of Textbooks on Animal Embryology and Reproduction Based on Research Results in the Development of Mice Embryos by Adding DEET (Diethyltoluamide)
}

\author{
Wiwik Kusmawati1,a*, Nikmatul Iza ${ }^{1, b}$, Nurmala Hindun ${ }^{1, c}$, and Fuad Azhar Nuh,d \\ 1Department of Biology Education, Faculty of Exact and Sports Science Education, IKIP Budi Utomo, Malang, 65119, Indonesia \\ a wiwikkusmawati@gmail.com; b nikmatuliza23.kendedes@gmail.com; c nurmalahindun01@gmail.com; d reffuad@gmail.com \\ *Corresponding Author \\ Whatsapp Number [+62-85790760080]
}

How to Cite: Kusmawati, W., Iza, N., Hindun, N. \& Nuh, F.,A. (2019).Development of Textbooks on Animal Embryology and Reproduction Based on Research Results in the Development of Mice Embryos by Adding DEET (Diethyltoluamide). International Journal for Educational and Vocational Studies, 1(4), 345-348

\section{ARTICLE HISTORY}

Received: 14 May 2019

Revised: 20 June2019

Accepted: 17 July 2019

KEYWORDS

Textbooks;

Animal Embryology;

Reproduction;

Embryo development;

\section{ABSTRACT}

The purpose of this study was to develop a textbook on Embryology and Animal Reproduction based on the research on the development of mouse embryos by adding DEET (Diethyltoluamide) that was appropriate and validated by material, media and language experts. This research is a development study of textbooks on animal embryology and reproduction based on the results of research on the development of mouse embryos by adding DEET. The development of this textbook refers to the 4D model developed by Thiagarajan, et al. (1974) which consisted of 4 stages, namely Define, Design, Development, and Disseminate, which were modified to be adapted to this study. This development research produced a textbook on Embryology and Animal Reproduction based on research on the development of mouse embryos by adding proper DEET and validating it by material, media and language experts.

\section{INTRODUCTION}

The rapid development of science and technology encourages higher education to always hold curriculum updates that will impact on changes in the components of course content and textbooks used. Textbooks are supporting the success of learning. A varied and complete textbook can support the learning process in order to achieve the expected goals. The purpose of developing textbooks is to help facilitate the learning process of students so that the preparation requires special requirements that must be met.

Mbulu, et al. (2004) say these specific requirements include: (1) Providing an orientation to theory, reasoning theory, and ways of applying theory in practice, (2) There are exercises on the use of theory and its application, (3) Teaching materials to provide bait (4) Adapting information and tasks to the level of student development, (5) Generating student interest, (6) Explaining learning objectives to students, (7) Increasing student motivation, and (8) Showing other sources of information.
The Directorate General of Higher Education (2009) said that textbooks are handbooks for subjects written and compiled by experts in related fields and fulfilling the rules of textbooks. In the field of education, textbooks are closely related to the learning process and curriculum. Textbooks are a means for implementing education and learning. During learning, the teacher can manage learning activities with the help of books. Students or students can participate in learning activities through book means.

The observation results in the seventh semester of 2017 in the Biology Study Program of IKIP Budi Utomo Malang revealed that textbooks on Animal Embryology and Reproduction courses containing material and practical activities on the development of mouse embryos by giving various doses of DEET (Diethyltoluamide) did not yet exist teach Animal Embryology and Reproduction courses that contain material for developing embryo of mice by giving various DEET doses and testing methods, as well as practical activities to test the effect of various doses of 
DEET on mouse embryo development, so that Animal Embryology and Reproduction learning is more contextual for students. Through research and development of this textbook, students will better understand the development of mouse embryos by treating various doses of DEET. Animal Embryology and Reproduction courses are one of the subjects in the Elective Course (MKP) group, and are prerequisite courses in the scope of the Biology IKIP Budi Utomo Study Program Malang.

Kusmawati (2005) said that the administration of DEET at a dose of $0 ; 281.25 ; 562,5 ; 1125$ and $2250 \mathrm{mg} / \mathrm{kg}$ BB dermally there were no significant differences in the number of live and dead mothers, maternal weight gain, number of live fetuses, fetal weight, fetal length, implantation, number of dead fetuses, number of resorption and intrauterine death. DEET does not cause fetal skeletal abnormalities of mice which include the supraocipital bone, sternum bone, vertebral bone, sacrokaudal bone and member phalanx bone. The results of this study are important to be implemented in the form of textbooks on Animal Embryology and Reproduction courses.

\section{METHODS}

This study is the development of textbooks on Animal Embryology and Reproduction courses based on the results of research on the development of mouse embryos (Mus musculus Galur BALB / C) by administering various doses of DEET (Diethyltoluamide). The development of this textbook refers to the $4 \mathrm{D}$ model developed by Thiagarajan, et al. (1974) which consisted of 4 stages, namely Define, Design, Development, and Disseminate, which were modified to be adapted to this study.

\subsection{Define Stage}

At this stage, an instructional needs analysis is needed for the development of textbooks covering the following steps: (1) Analyzing basic competencies in Animal Embryology and Development courses, (2) Identifying learning problems, and (3) Identifying weaknesses and shortcomings of textbooks Animal Embryology and Development based on the results of research on the development of mouse embryos by adding DEET.

\subsection{Design Stage}

This stage was carried out to produce an initial draft textbook on Embryology and Animal Development based on the results of research on the development of mouse embryos by adding DEET.

\subsection{Stage of Develop}

This stage aims to revise the initial draft textbook that has been prepared at the design stage. The revision is based on the validation process carried out by material experts, media experts (teaching materials experts), and linguists. After the validation and revision is complete, the development test is carried out as follows: First, test of individuals and small groups with the subjects of
Biology Education Study Program students who have taken courses in Animal Embryology and Development. Second, Test in actual learning through Classroom Action Research.

\subsection{Disseminate stage}

The result of the desiminate stage is the dissemination of textbooks to be used in lectures on Animal Reproduction and Reproduction especially for the Biology Study Program of IKIP Budi Utomo Malang.

\section{RESULTS AND DISCUSSION}

\subsection{Results of Define Phase}

The define (initial analysis) stage of the researcher conducted interviews with students who had participated in previous Animal Embryology and Reproduction courses. The results obtained are information that the Animal-based Embryology and Reproduction textbooks based on research on the development of mouse embryos (Mus musculus Galur BALB / C) with various doses of DEET (Diethyltoluamide) do not yet exist, so the development of research-based Animal Embryology and Reproduction textbooks is needed. development of mouse embryos (Mus musculus Galur BALB / C) by administering various doses of DEET (Diethyltoluamide).

\subsection{Results of Design Phase}

As Thiagarajan (1974: 6) argues that the selection of media and the format for the material and production of an initial version of teaching material are the main aspects of the design phase, the researcher chose the A5 paper size for the draft book. The covers and pages per chapter are designed with Adobe Photoshop.

The results of this stage are to produce a draft textbook consisting of cover (cover page), preface, table of contents, instructions for use, and basic competencies in each chapter. The contents section consists of introductory material, main material, sample questions and exercises.

The cover section is given a blue color reflecting the color identity of the IKIP Budi Utomo Malang campus. The front cover contains the titles of books, authors, and institutions. While the back cover contains a brief description of the Animal Embryology and Reproduction textbook based on the research on the development of mouse embryos (Mus musculus Galur BALB / C) by administering various doses of DEET (Diethyltoluamide). 

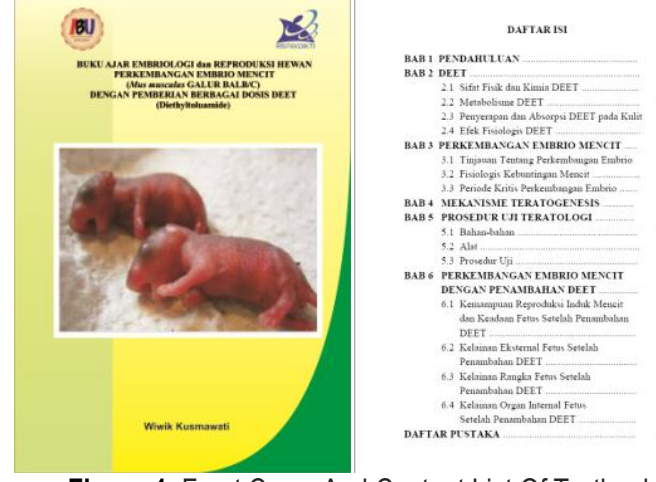

Figure 1. Front Cover And Content List Of Textbook

\subsection{Results of Develop Phase}

This textbook is validated by three experts, namely material, media and language experts. Material Validator by Ms. Lia Rahayu, S.Si., M.Sc., media validator by Mr. Anangga Widya Pradipta, S.Pd, M.Pd., and language validator by Ms. Dra. Nurmala Hindun, M.Kes. The results of the assessment of each validator are calculated and made in the form of percentages.

Table 1. Results of Material Expert Validation

\begin{tabular}{ccc}
\hline \multirow{2}{*}{ Code validator } & \multicolumn{2}{c}{ Validation results } \\
\cline { 2 - 3 } & $\%$ & Criteria \\
\hline V1 & 87,5 & Worthy of a very good predicate \\
\hline
\end{tabular}

Table 2. Results of Media Expert Validation

\begin{tabular}{ccc}
\hline \multirow{2}{*}{ Code validator } & \multicolumn{2}{c}{ Validation results } \\
\cline { 2 - 3 } & $\%$ & Criteria \\
\hline V2 & 82,5 & Worthy of a good predicate \\
\hline
\end{tabular}

Table 3. Results of Language Expert Validation

\begin{tabular}{ccc}
\hline \multirow{2}{*}{ Code validator } & \multicolumn{2}{c}{ Validation results } \\
\cline { 2 - 3 } & $\%$ & Criteria \\
\hline V3 & 80 & Worthy of a good predicate \\
\hline
\end{tabular}

The average validation results from the three validators were $83.3 \%$ in the criteria of decent and good. In addition to assessments in the form of numbers, the validator provides several suggestions as a reference for the action of revision of textbooks, among others.

Table 4. Advice/Comentar from Media Experts

\begin{tabular}{|c|c|c|}
\hline No. & Error Type & $\begin{array}{l}\text { Recommendation for } \\
\text { Improvement }\end{array}$ \\
\hline 1. & Use of foreign languages & The letter is tilted \\
\hline 2. & The page does not yet exist & Added page \\
\hline 3. & $\begin{array}{l}\text { There are no training } \\
\text { questions }\end{array}$ & $\begin{array}{l}\text { Coupled with } \\
\text { questions }\end{array}$ \\
\hline
\end{tabular}

Table 5. Advice/Comentar from Language Experts

\begin{tabular}{cl}
\hline No. & Comments / Suggestions from Linguists \\
\hline 1. & The language used is easy to understand and \\
in accordance with the Enhanced Spelling \\
(EYD)
\end{tabular}

2. There is already a connection between nutrition and the world of sports

\subsection{Stage Desiminate results}

The result of the desiminate stage is the dissemination of textbooks to be used in lectures on Animal Reproduction and Reproduction especially for the Biology Study Program of IKIP Budi Utomo Malang.

\section{CONCLUSION}

This development research produced textbooks based on research on the development of animal embryology and reproduction in the development of mouse embryos (Mus musculus galur BALB/C) by administering various doses of DEET (Diethyltoluamide) that were appropriate and validated by material, media and language experts.

\section{REFERENCES}

Adalikwu, S.A., dan I.T. Iorkpilgh, 2013, The Influence of Instructional Materials on Academic Performance of Senior Secondary School Students in Chemistry in Cross River State, Global Journal of Educational Research, 20 (1).

Arikunto, S, 1993, Prosedur Penelitian Suatu Pendekatan Praktik. Edisi Revisi, Rhineka Cipta, Jakarta.

Departemen Pendidikan Nasional, 2008, Peraturan Nomor 2 Tahun 2008 Tentang Buku,

http://mediainfo.sourceforge.net/, Diakses tanggal 2 Januari 2013.

Direktorat Jenderal Pendidikan Tinggi. 2009, Pedoman Operasional Penilaian Angka Kredit Kenaikan Jabatan Fungsional Dosen ke Lektor Kepala dan Guru Besar, Jakarta: Kemendiknas.

EXTOXNET (Extension Toxicology Network), 2002, DEET, http://pmep.cce.cornell.edu/profiles / Extoxnet/carbaryl-dicr otophos/deet-ext.html. Diakses 27 November 2017.

Kusmawati, W., 2005, Efek Embriotoksik dan Teratogenik Diethyltoluamide (DEET) Terhadap Perkembangan Embrio Mencit (Mus musculus) Galur BALB/C, Tesis, Universitas Airlangga, Surabaya.

Mbulu, J. dan Suhartono, 2004, Pengembangan Bahan Ajar, Elang Mas, Malang.

MOTIS (Missouri Teratogen Information Services), 2003, Bug Repellent and Pregnancy,

http://www.gnetics.missouri.edu/motis/bud_repellent_and_ pregnancy.htm, Diakses 27 November 2017).

Muslich, Masnur, 2010, Text Book Writing: Dasar-dasar Pemahaman, Penulisan, dan Pemakaian Buku Teks, Ar-Ruzz Media, Jogjakarta. 
Thiagarajan, S., Semmel, D.S., and Semmel, M.I., 1974, Instructional

Development for Training Teachers of Exceptional Children, National Center for Improvement of Educational, Washington.

Thiagarajan, 1974, Instructional Development for Training Teachers of Exceptional Children, University of Minnesota, New York-USA.

Prastowo, A., 2012, Panduan Kreatif Membuat Bahan Ajar Inovatif, Diva Press, Jogjakarta.

Sugiono, 2010, Metode Penelitian Kuantitatif Kualitatif dan R\&D, Alfabeta, Bandung.

Winarno, M. E., 2011, Metodologi Penelitian dalam Pendidikan Jasmani, Media Cakrawala Utama Press, Malang.

WNV (West Nile Virus), 2002, DEET (Insect Repellent), http://212.187.155.84/wnv/List_WPMod_Cont/westnile/Che mical?Deet.htm, Diakses 27 November 2017. 